\title{
Genetic differentiation in relation to restricted larval dispersal of the convict surgeonfish Acanthurus triostegus in French Polynesia
}

\author{
S. Planes \\ Ecole Pratique des Hautes Etudes, Centre de Biologie et d'Ecologie Tropicale et Méditerranéenne, URA CNRS 1453, \\ Université de Perpignan, F-66860 Perpignan Cedex, France \\ and \\ Ecole Pratique des Hautes Etudes, Antenne de Tahiti, Centre d'Opunohu, BP 1013, Moorea, Polynésie Française
}

\begin{abstract}
Genetic markers were used to study larval dispersal in coral reef fishes in order to investigate the impact of migration during the pelagic phase on island recruitment. Samples of Acanthurus triostegus were collected from 11 sites in French Polynesia in order to examine 3 different spatial scales (Island, Archipelago and Polynesia). To examine the effects of gene flow on population heterogeneity and population substructuring in A.triostegus, starch gel electrophoresis on 10 polymorphic loci encoding 10 enzymes was used [heterozygoty $(H)=0.325 \pm 0.045$; polymorphism level $\left(P_{0.95}\right)=0.323$ ]. Nei's genetic distances calculated on the 10 polymorphic loci were very high (between 0.004 and 0.194 with an average of 0.058 ) and $G$-tests made on a single locus between pairwise samples showed 5 groups to be significantly different: 1 group comprised samples from Tiahura, Tubuai, Maiao, Tetiaroa, Pt. Paroa and Tahiti; 1 group comprised samples from Muroroa and Managreva and 3 other groups comprised the isolated samples from Takapoto, Bora-Bora and Nuku-Hiva respectively. Fixation index $\left(F_{\mathrm{sl}}\right)$ values indicate significant differentiation between the 11 samples $\left(F_{\mathrm{st}}=0.0886\right.$ on 11 populations $)$, even between Bora-Bora and Moorea which are separated by $250 \mathrm{~km}$. Estimates of gene flow $\left(\mathrm{N}_{\mathrm{e}} \mathrm{m}\right.$ : absolute numer of migrants at equilibrium), assuming equilibrium between the samples, were $\leq 10$ individuals per generation, which is sufficient to ensure that the same alleles will be shared over long periods, but not sufficient to maintain identical allelic frequencies between populations. A hypothesis is proposed to illustrate the genetic structure of $A$. triostegus observed in French Polynesia based on ocean currents and the behaviour of the larval oceanic phase.
\end{abstract}

\section{INTRODUCTION}

The life history of most coral reef fishes is divided into 2 very dissimilar stages (Sale 1980): a relatively sedentary adult and juvenile stage and a planktonic egg and/or larval stage. Two reproductive strategies are also reported for coral reef fishes by Hourigan \& Reese (1987). The first strategy is one whereby demersal eggs are protected by the adults, and is associated with low fecundity (25 to 10000 eggs) and short larval duration (15 to $30 \mathrm{~d})$. The second strategy is characterised by planktonic eggs, high fecundity (100 to 1000000 eggs) and a longer larval stage (from 20 to $80 \mathrm{~d}$ ). Existence of a larval planktonic stage has led to the conclusion that there is considerable potential for dispersal and migration between geographically separated populations. The prevailing view is that reefs exist as spatially subdivided populations interconnected by pelagic larval exchanges (Mapstone \& Fowler 1988). However, the distribution of coral reef fish in the Pacific suggests a high level of isolation between islands: only about 800 species occur in French Polynesia, compared to 1500 on the Australian Great Barrier Reef and 2180 in the Philippines (Sale 1980, Springer 1982, Randall 1985). Moreover, there is no direct relationship between the fish species occurring in French Polynesia and the larval duration of these species.

The aim of the present study was to evaluate the effect of larval dispersal on genetic homogeneity of 
island populations of Acanthurus triostegus in French Polynesia. Two alternative hypotheses for the fate of larvae are proposed: (1) That larvae remain near the island where they were spawned and return to it before settling from the plankton. This is the localrecruitment concept. With local recruitment, and an absence of migration between islands, each population is isolated and inter-island genetic differentiation should develop with time. (2) That larvae are transported by currents and recruit to the first island they encounter. This is the random-recruitment concept. In this case, no genetic differentiation between islands is expected.

Of the published electrophoretic studies intended to assess subdivision of coral reef fish populations on a macrogeographic scale (Somero \& Soulé 1974, Gorman \& Kim 1977, Vawter et al. 1980, Bell et al. 1982, Shaklee 1984, Lacson 1992) only Bell et al. (1982) provide evidence for genetic differentiation between isolated populations. This study, made on Amphiprion clarkii along the coast of southern Japan, revealed an average genetic distance (Nei's distance) value of 0.008 and heterogeneity was found to be significant for $37 \%$ of the tests carried out. Most of the differences were found between 5 sites on the Japanese coast and Bonin Islands, separated by about $1500 \mathrm{~km}_{\text {i }}$ the 5 coastal sites did not show any evidence of differentiation. The other studies support the existence of a panmictic population sustained by larval migration.

This paper aimed to determine whether or not Acanthurus triostegus constitutes a single panmictic population in French Polynesia.

\section{MATERIALS AND METHODS}

The convict surgeonfish or manini Acanthurus triostegus is found throughout the tropical IndoPacific, including Madagascar, Australia, Japan, Hawail and Polynesia, and the Gulf of Mexico. The sexes are separate and each female can lay more than 100000 eggs each year (Randall 1961). The reproductive cycle varies with localities and shows sedsonality in French Polynesia, associated with the warm period. Reproduction occurs during the day, in groups of hundreds of individuals, near channels through the reef. This species has pelagic eggs and a larval duration estimated at between 60 and $70 \mathrm{~d}$. Their distribution during the oceanic stage is poorly documented. However, larvae are reported at about $50 \mathrm{~m}$ depth around Hawaii (Randall 1961) and the highest concentrations of larvae are found in 13 to $20 \mathrm{~m}$ depth in the Great Barrier Reef (Leis 1991). Competent postlarvae returning to the reef measure 20 to $25 \mathrm{~mm}$ before settlement. This species was chosen mainly because it is very abundant in French Polynesia and therefore presented no sampling problems. Moreover, its broad distribution was an advantage because a larger-scale study was planned.

Sampling. A total of 406 surgeonfish (>60 mm total length) were captured from 11 sites during 15 November 1990 to 15 February 1991 using spear-fishing techniques. The fish were measured, then dissected in order to isolate the liver, the eyes and part of the dorsal muscle (a piece of 1 or $2 \mathrm{~g}$ ). The tissues were stored at $-80^{\circ} \mathrm{C}$ in liquid nitrogen to prevent possible degradation of the enzymatic activity. The 11 sites were chosen to represent 3 spatial scales (Fig. 1). For the Island spatial scale, 2 samples ( 39 and 31 fish respectively) were collected from Pt. Paroa and Tiahura on Moorea Island. For the Archipelago spatial scale, 5 samples $(39,39,32$, 39 and 40 fish respectively) were caught off Moorea, Tetiaroa, Bora-Bora, Maiao and Tahiti, islands of the Society Archipelago. For the Polynesia spatial scale, 6 samples $(40,32,39,40,39$ and 36 fish respectively) were collected off Tahiti, Takapoto, Tubuai, Mangareva, Nuku-Hiva and Mururoa, islands from 5 different Polynesian archipelagoes. All fish were collected in the lagoon habitat, except for the atolls of Takapoto, Mururoa and Tetiaroa, where the fish were sampled on the ocean side of the reef, and Nuku-Hiva where there is no coral reef.

Enzyme analysis. Each piece of tissue was homogenised at $4{ }^{\circ} \mathrm{C}$ in an equal volume of Tris/EDTA/ NADP buffer ( $\mathrm{pH} 6.8$ ). The homogenenates were centrifuged at $15000 \times g$ for $30 \mathrm{~min}$ at $4^{\circ} \mathrm{C}$. The supernatant was stored at $-80^{\circ} \mathrm{C}$. The samples were then processed by routine electrophoresis. The protocol for enzyme electrophoresis on horizontal starch was essentially that of Pasteur et al. (1987), and the nomenclature of the enzymes followed Shaklee et al. (1990).

Thirty-one enzyme loci with clearly interpretable genetic variation were scored (see Table 1). A locus was considered polymorphic if the frequency of the most common allele was $\leq 0.95$ in at least 1 population. Alleles at polymorphic loci were assigned numerical designations expressing the mobility of their respective protein products relative to the mobility of the most common allozyme (designated 100) among the samples.

Statistical analyses. Allele frequencies at polymorphic loci were determined. Genotypic frequencies at polymorphic loci were tested for conformity to HardyWeinberg expectations using Emigh's (1980) correction and adjusting the significance levels for multiple tests (Lessios 1992). The present study comprised 110 tests (11 populations $\times 10 \mathrm{loci}$ ) and the 0.05 adjusted significance level become $4.54 \times 10^{-4}$. The chi-square value for this level of significance was computed by 


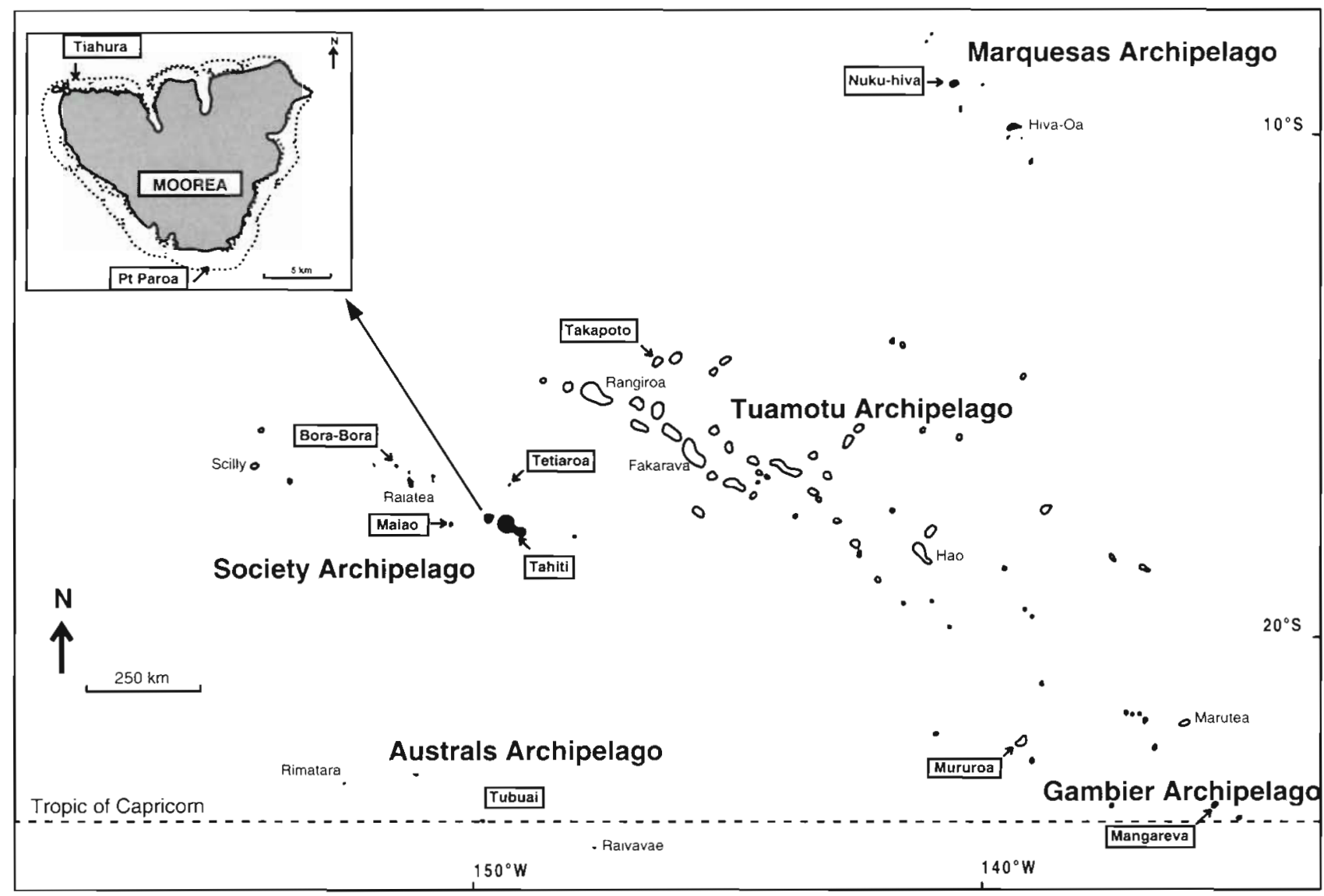

Fig. 1. Acanthurus triostegus. Sampling sites (denoted by rectangles)

randomising 10000 values from the chi-square distribution. The 5 th highest value was taken to represent the 0.0005 level of significance; the highest of 10 repeat computations was used in order to prevent Type I statistical errors

Estimates of genetic divergence among samples were obtained using 2 different methods, (1) Comparisons of genetic differences among samples were assessed by $G$-test pairwise sample computations and genetic distances ( $D$ : Nei 1978) between the 11 populations, and the resulting matrix subjected to cluster analysis using the UPGMA algorithm (Sneath \& Sokal 1973). Significance of the Nei's genetic distances and the UPGMA resulting was tested by determining the standard deviation of $D$ (Nei 1987): variance of $D=$ $(1-I) /($ In $)$, where $I=$ Nei's genetic identity and $\mathrm{n}=$ number of loci. For the $G$-test, the $\mathrm{p}$-values were adjusted using the correction for multiple non-independent tests (Rice 1989), an $\alpha$ level of 0.05 becomes 0.0009 (corrected to 0.001 ). Analyses were performed using 'Genes in Populations', a computer program designed by B. May and C. C. Krueger and written by W. Eng (Cornell University, Ithaca, NY, USA).
(2) F-statistics were computed following the method of Weir \& Cockerham (1984) using Eq. (10) for multiple loci and the algorithm described by Reynolds et al. (1983) for weighting of multiple alleles. A chi-square test (Workman \& Niswander 1970) was used to evaluate the null hypothesis, $F_{\mathrm{st}}=0: \chi^{2}=2 \mathrm{~N} F_{\mathrm{st}}(k-1)$; $\mathrm{df}=(k-1)(s-1)$, where $\mathrm{N}$ is the total number of individuals sampled; $k$ is the number of alleles at the locus: $s$ is the number of populations

Estimations of the absolute number of migrants at equilibrium $\left[\mathrm{N}_{\mathrm{e}} \mathrm{m}=\left(1-F_{\mathrm{st}}\right) / 4 F_{\mathrm{st}}\right.$; Wright 1951] were calculated as an estimate of gene flow between populations. $N_{e} m$ was calculated from the $F_{s 1}$ values from the Island model with a small level of migration. It represents the number of migrant individuals for each generation at equilibrium. The $\mathrm{N}_{\mathrm{e}} \mathrm{m}$ estimates assume an equilibrium between drift and migration. Moreover, it is generally accepted that 1 migrant individual per local population per generation is sufficient to obscure the effect of genetic drift (Speith 1974). While this principle is correct, it is inappropriate when applied to the analysis of population structure at a single point in time; 1 migrant is sufficient to ensure that the same 
allele will be shared over long periods of time, but is not sufficient to maintain identical allelic frequencies between populations (Allendorf \& Phelps 1981).

\section{RESULTS}

Of the 31 loci examined, 16 were monomorphic in all the samples while 5 demonstrated infrequent allelic variation; the latter comprised Idh- $f, I d h-m, A A T-1$, $A A T-3$ and $G P D$ (Table 1). Finally, significant polymorphism was observed in 10 loci corresponding to a polymorphism level $\left(P_{0.95}\right)$ of 0.323 (Table 2 ). The variation in allelic frequency of the most common allele in each locus was large and was not attributable to sampling errors. Variation was greatest at 8 loci: PGI-1 where the frequency of the most common allele varied from 0.73 to $0.94, A A T-2(0.40$ to 0.98$), A D H(0.42$ to 0.88$)$,
$S D H(0.28$ to 0.73$), A D A(0.49$ to 1.00$), G D A(0.33$ to $0.97), M D H-2(0.22$ to 0.99$)$ and $H P D(0.12$ to 0.59$)$.

Significant deviation of genotypic frequencies from the Hardy-Weinberg equilibrium was observed in only 3 instances: $A D H$ and $M D H$ presented a slight excess of heterozygotes in Pt. Paroa and Mururoa respectively and GDA in Maiao exhibited a significant deviation corresponding to a deficiency of heterozygotes (chisquare $=16.57, \mathrm{df}=1, \mathrm{p}<0.005$ ). For the remaining loci, large chi-square values resulted from low expected frequencies of genotypes observed in 1 or 2 individuals. Those deviations represented only $2.7 \%$ of the 110 tests carried out and thus can be considered as a sampling error. Data from all the different samples were pooled and conformity to Hardy-Weinberg expectations was tested. Six loci presented significant deviation: $P G I-1$ (chi-square $=12.373, \mathrm{df}=2, \mathrm{p}<0.005$ ) AAT -2 (chi-square $=5.26, \mathrm{df}=1, \mathrm{p}<0.025$ ), $S D H$ (chi-

Table 1. Acanthurus triostegus. Enzyme systems with corresponding tissues and buffers. $\cdot$ polymorphic enzymatic system; A: discontinuous buffer Tris-citrate-borate (TCB, $\mathrm{pH} 8.7$ ); $\mathrm{B}$ : discontinuous buffer Tris- $\mathrm{HCl}$ ( $\mathrm{pH} 8.5$ ); $\mathrm{C}$ : continuous buffer Tris-citrate (TC, $\mathrm{pH} 6.7$ ); D: continuous buffer Tris-citrate (TC, $\mathrm{pH} 8.0$ )

\begin{tabular}{|c|c|c|c|}
\hline Enzymes & Locus & Buffer & Tissue \\
\hline Lactate dehydrogenase & $\begin{array}{l}L d h-1 \\
L d h-2 \\
L d h-3\end{array}$ & $\begin{array}{l}\text { A } \\
\text { A } \\
\text { A }\end{array}$ & $\begin{array}{l}\text { Eyes } \\
\text { Eyes } \\
\text { Eyes }\end{array}$ \\
\hline Malate dehydrogenase & $\begin{array}{l}M d h-1 \\
M d h-2\end{array}$ & $\begin{array}{l}\mathrm{D} \\
\mathrm{D}\end{array}$ & $\begin{array}{l}\text { Eyes } \\
\text { Eyes }\end{array}$ \\
\hline Isocitrate dehydrogenase & $\begin{array}{l}I d h-f^{*} \\
I d h-m^{*}\end{array}$ & $\begin{array}{l}\mathrm{C} \\
\mathrm{C}\end{array}$ & $\begin{array}{l}\text { Liver } \\
\text { Muscle }\end{array}$ \\
\hline 6 Phosphogluconate dehydrogenase & $6 P G D$ & $\mathrm{C}$ & Eyes \\
\hline$\alpha$-Glycerophosphate dehydrogenase & $G P D^{\bullet}$ & $\mathrm{D}$ & Muscle \\
\hline Sorbitol dehydrogenase & $S d h^{*}$ & $\mathrm{~B}$ & Liver \\
\hline Alcohol dehydrogenase & $A d h^{\bullet}$ & A & Liver \\
\hline Hexose phosphate dehydrogenase & $H P D^{\cdot}$ & A & Liver \\
\hline Glucose phosphate isomerase & $\begin{array}{l}\text { PGI-1. } \\
\text { PGI-2. }\end{array}$ & $\begin{array}{l}\mathrm{A} \\
\mathrm{A}\end{array}$ & $\begin{array}{l}\text { Eyes } \\
\text { Eyes }\end{array}$ \\
\hline Phosphoglucomutase & $P G M$ & $\mathrm{C}$ & Muscle \\
\hline Malic enzyme & $\begin{array}{l}M e-1 \\
M e-2\end{array}$ & $\begin{array}{l}\mathrm{D} \\
\mathrm{D}\end{array}$ & $\begin{array}{l}\text { Muscle } \\
\text { Muscle }\end{array}$ \\
\hline Mannose 6 phosphate isomerase & $M P I$ & $\mathrm{C}$ & Muscle \\
\hline Super oxide dismutase & $\begin{array}{l}\text { Sod-1 } \\
\text { Sod-2 }\end{array}$ & $\begin{array}{l}\mathrm{A} \\
\mathrm{A}\end{array}$ & $\begin{array}{l}\text { Liver } \\
\text { Liver }\end{array}$ \\
\hline Fumarase & Fum & A & Muscle \\
\hline Adenosine diaminase & $A D A^{\circ}$ & $\mathrm{C}$ & Muscle \\
\hline Guanine deaminase & $G D A^{*}$ & $\mathrm{C}$ & Liver \\
\hline Aspartate aminotransferase & $\begin{array}{l}A A T-1^{\circ} \\
A A T-2^{\circ} \\
A A T-3^{\circ}\end{array}$ & $\begin{array}{l}C \\
C \\
C\end{array}$ & $\begin{array}{l}\text { Liver } \\
\text { Liver } \\
\text { Muscle }\end{array}$ \\
\hline Adenylate kinase & $A K$ & $\mathrm{D}$ & Eyes \\
\hline Creatine kinase & $C K$ & $\mathrm{C}$ & Liver \\
\hline Glyoxylase-1 & GLO & A & Liver \\
\hline Leucine aminopeptidase & Lap & $D$ & Muscle \\
\hline Esterases & Est & B & Liver \\
\hline
\end{tabular}


Table 2. Acanthurus triostegus. Allele frequencies at 10 polymorphic loci for 11 sites. The most common allele is designated 100 . $\mathrm{N}$ : number of alleles analysed at each locus

\begin{tabular}{|c|c|c|c|c|c|c|c|c|c|c|c|c|}
\hline $\begin{array}{l}\text { Locus } \\
\qquad \text { Alleles }\end{array}$ & Tubuai & $\begin{array}{l}\text { Nuku- } \\
\text { Hiva }\end{array}$ & $\begin{array}{c}\text { Manga- } \\
\text { reva }\end{array}$ & $\begin{array}{l}\text { Taka- } \\
\text { poto }\end{array}$ & Mururoa & Tahiti & $\begin{array}{c}\text { Bora- } \\
\text { Bora }\end{array}$ & Tetiaroa & Maiao & Pt. Paroa & Tiahura & Total \\
\hline \multicolumn{13}{|l|}{$P G l-1$} \\
\hline 120 & - & 0.01 & 0.01 & - & 0.01 & - & - & - & - & - & - & $<0.01$ \\
\hline 100 & 0.76 & 0.95 & 0.83 & 0.71 & 0.81 & 0.81 & 0.81 & 0.81 & 0.78 & 0.82 & 0.83 & 0.81 \\
\hline 70 & 0.24 & 0.04 & 0.16 & 0.29 & 0.18 & 0.19 & 0.19 & 0.19 & 0.22 & 0.18 & 0.17 & 0.19 \\
\hline \multicolumn{13}{|l|}{$P G I-2$} \\
\hline 120 & 0.06 & 0.18 & 0.05 & 0.06 & 0.04 & 0.08 & 0.02 & 0.06 & 0.03 & 0.01 & 0.08 & 0.07 \\
\hline 100 & 0.94 & 0.82 & 0.94 & 0.92 & 0.95 & 0.91 & 0.98 & 0.94 & 0.97 & 0.99 & 0.92 & 0.93 \\
\hline 70 & - & - & 0.01 & 0.02 & 0.03 & 0.01 & - & - & - & - & - & $<0.01$ \\
\hline \multicolumn{13}{|l|}{$A A T-2$} \\
\hline 140 & 0.24 & 0.01 & 0.50 & 0.33 & 0.60 & 0.23 & 0.27 & 0.19 & 0.24 & 0.11 & 0.30 & 0.28 \\
\hline 100 & 0.76 & 0.98 & 0.50 & 0.65 & 0.40 & 0.77 & 0.73 & 0.81 & 0.76 & 0.89 & 0.70 & 0.72 \\
\hline 70 & - & 0.01 & - & 0.02 & - & - & - & - & - & - & - & 0.01 \\
\hline \multicolumn{13}{|l|}{$A D H$} \\
\hline 100 & 0.50 & 0.10 & 0.44 & 0.59 & 0.58 & 0.44 & 0.39 & 0.38 & 0.44 & 0.56 & 0.42 & 0.44 \\
\hline 50 & 0.50 & 0.90 & 0.56 & 0.41 & 0.42 & 0.56 & 0.61 & 0.62 & 0.56 & 0.44 & 0.58 & 0.56 \\
\hline \multicolumn{13}{|l|}{ SDH } \\
\hline 100 & 0.55 & 0.72 & 0.71 & 0.61 & 0.33 & 0.27 & 0.50 & 0.50 & 0.64 & 0.48 & 0.56 & 0.53 \\
\hline 20 & 0.45 & 0.28 & 0.29 & 0.39 & 0.67 & 0.73 & 0.50 & 0.50 & 0.36 & 0.52 & 0.44 & 0.47 \\
\hline \multicolumn{13}{|l|}{ PGM } \\
\hline 110 & - & - & 0.02 & - & - & 0.01 & - & 0.01 & - & - & - & $<0.01$ \\
\hline 100 & 1.00 & 1.00 & 0.89 & 1.00 & 0.96 & 0.97 & 0.91 & 0.94 & 0.96 & 0.94 & 0.97 & 0.96 \\
\hline 60 & - & - & 0.09 & - & 0.03 & 0.01 & 0.09 & 0.04 & 0.04 & 0.06 & 0.03 & 0.04 \\
\hline 20 & - & - & - & - & 0.01 & 0.01 & - & 0.01 & - & - & - & $<0.01$ \\
\hline \multicolumn{13}{|l|}{$A D A$} \\
\hline 100 & 0.63 & 1.00 & 0.49 & 0.50 & 0.61 & 0.84 & 0.67 & 0.66 & 0.69 & 0.71 & 0.73 & 0.69 \\
\hline 90 & 0.31 & - & 0.50 & 0.48 & 0.38 & 0.15 & 0.33 & 0.33 & 0.30 & 0.25 & 0.25 & 0.29 \\
\hline 60 & 0.06 & - & 0.01 & 0.02 & 0.01 & 0.01 & - & 0.01 & 0.01 & 0.04 & 0.02 & 0.02 \\
\hline \multicolumn{13}{|l|}{$G D A$} \\
\hline 140 & 0.27 & 0.21 & 0.06 & 0.44 & 0.03 & 0.06 & 0.67 & 0.03 & 0.18 & 0.16 & 0.23 & 0.23 \\
\hline 100 & 0.70 & 0.79 & 0.94 & 0.56 & 0.97 & 0.94 & 0.33 & 0.96 & 0.82 & 0.84 & 0.77 & 0.77 \\
\hline 70 & 0.03 & - & - & - & - & - & - & 0.01 & - & - & - & $<0.01$ \\
\hline \multicolumn{13}{|l|}{$M D H$} \\
\hline 100 & 0.54 & 0.01 & 0.59 & 0.62 & 0.54 & 0.78 & 0.64 & 0.72 & 0.60 & 0.71 & 0.56 & 0.58 \\
\hline 50 & 0.46 & 0.99 & 0.41 & 0.38 & 0.46 & 0.22 & 0.36 & 0.28 & 0.40 & 0.29 & 0.44 & 0.42 \\
\hline \multicolumn{13}{|l|}{$H P D$} \\
\hline 120 & 0.56 & 0.45 & 0.51 & 0.88 & 0.56 & 0.54 & 0.42 & 0.53 & 0.41 & 0.54 & 0.59 & 0.54 \\
\hline 100 & 0.44 & 0.55 & 0.49 & 0.12 & 0.44 & 0.46 & 0.58 & 0.47 & 0.59 & 0.46 & 0.41 & 0.46 \\
\hline $\mathrm{N}$ & 78 & 78 & 80 & 64 & 72 & 80 & 64 & 78 & 78 & 78 & 62 & 812 \\
\hline
\end{tabular}

square $=6.34, \mathrm{df}=1, \mathrm{p}<0.025)$, ADA (chi-square $=$ 15.93, df $=3, \mathrm{p}<0.005)$, GDA (chi-square $=50.12$, $\mathrm{df}=3, \mathrm{p}<0.005$ ) and $H P D$ (chi-square $=7.31, \mathrm{df}=1$, $p<0.01$ ). Pooling of all the samples introduced disequilibrium to the population due to differences between samples.

Nei's genetic distances $(D)$ were estimated using 31 loci (Table 3), and the dendrogram was constructed based on these genetic distances (Fig. 2). The major branch of the dendrogram separates Nuku-Hiva from all the other samples; and the $G$-test realised for single loci shows that divergences are caused mainly by 4 loci $(A A T-2, A D H, A D A$ and $M D H)$ and leave no doubt as to the discreteness of this origin. The dendrogram also separates Takapoto and Bora-Bora from Mururoa and Mangareva and from a group mainly comprising Society Archipelago samples. However, because distortion can occur when clustering, the UPGMA dendrogram cannot be used as a definitive analysis to separate populations. Using the estimation of the variance of $D$, the value of 0.032 appears as the limit of significance. According to that limit, the UPGMA tree shows 6 groups to be significantly different: 1 group comprised samples from Tiahura, Tubuai, Maiao, Tetiaroa, Pt. Paroa and Tahiti and 5 other groups each comprised a single sample. However, because the nodes between 


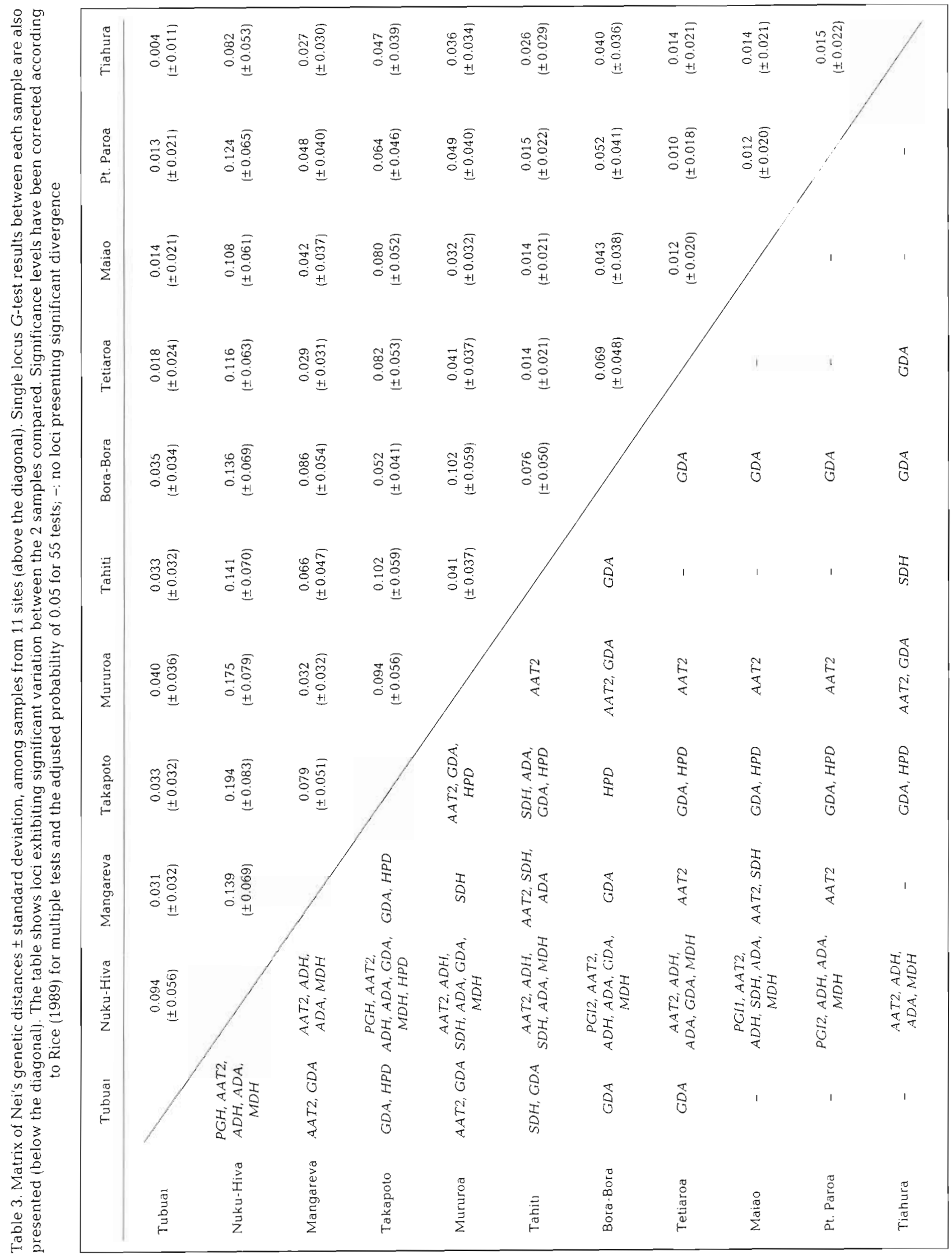


Mururoa and Mangareva are located just at the limit of significance, it seems reasonable to consider those 2 samples as a unique group. This will lead to the differentiation of 5 groups from $D$ and the UPGMA analysis.

The $G$-test was used to test for statistically significant differences in the allele frequencies of each single locus between each pairwise comparison (Table 2). Thirteen pairwise comparisons between sample sites did not show any significant divergence in any locus. The nonsignificant comparisons were mainly between Tahiti, Tubuai, Tetiaroa, Maiao and Moorea (Pt. Paroa and Tiahura) samples. However, some unexpected results were found in the pairwise comparions, such as the absence of differentiation between Mangareva and Tiahura or the significant divergence between Tiahura and Tahiti or Tiahura and Tetiaroa. From the single locus G-test, GDA appears as the most variable locus responsible for the divergence of Bora-Bora from the other sample of the Society Archipelago. Finally, the G-tests performed over single loci confirm the results found previously in the analysis of $D$, by resulting in the same groups. In this case the samples from Mururoa and Mangareva are divergent in only 1 locus $(S D H)$ of the 10 and no conclusion can be drawn about the differentiation of the 2 samples because of sampling error.

The mean fixation indices $\left(F_{\mathrm{st}}\right)$ were calculated for different clusters that were established by the sequential removal of samples that introduced variability (Table 4). Global $F_{5 t}$ on 11 populations was estimated as 0.089 from Weir \& Cockerham's (1984) methods and was highly significant. A specific estimation between Moorea (pooling the 2 Moorea samples) and Tahiti, 2 islands only $17 \mathrm{~km}$ apart, showed a significant $F_{\text {st }}$ of 0.025 indicating a significant divergence between the 2 islands. However, difference between Maiao, Tetiaroa and Moorea was not significant $\left(F_{\mathrm{st}}=0.007\right)$. Estimates of the number of migrants exchanged between the French Polynesian populations per generation $\left(\mathrm{N}_{\mathrm{e}} \mathrm{m}\right.$ ) were greater than $1, \mathrm{~N}_{\mathrm{e}} \mathrm{m}>2.57$ (Table 4), and because they are directly related to $F_{\mathrm{s}}$, they follow the results shown with $F_{51}$.

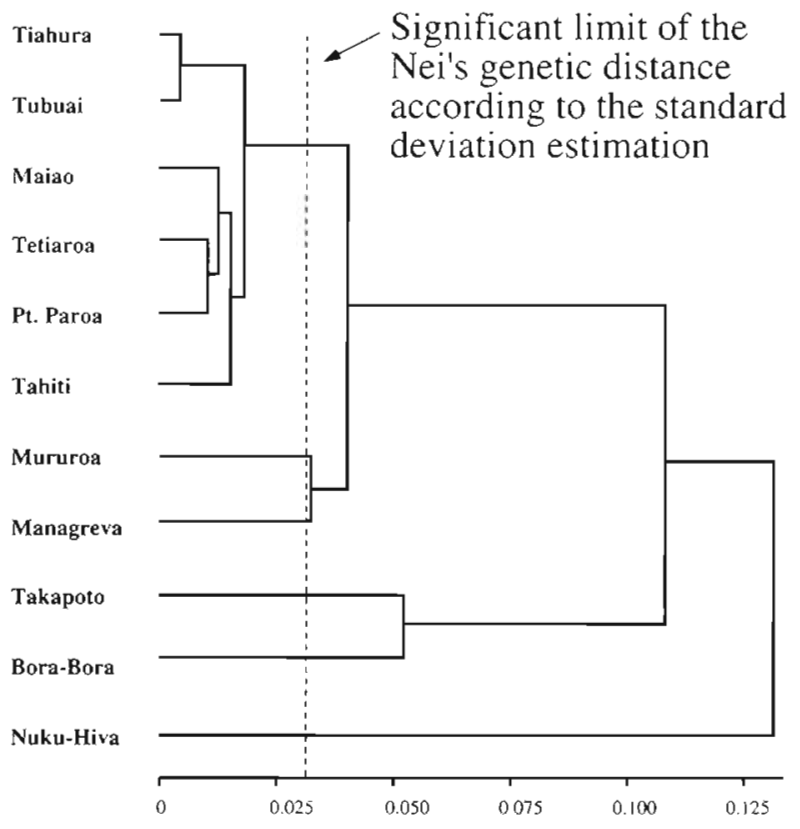

Fig. 2. Acanthurus triostegus. Dendrogram based on genetic distances between the 11 populations surveyed (see Table 3), using UPGMA clustering

\section{DISCUSSION}

The electrophoretic data and analyses demonstrate that populations of Acanthurus triostegus in French Polynesia do not represent a genetically homogeneous assemblage, with different units being discernable from the allelic data. According to the various analyses, 5 groups appear to be significantly different: 1 group comprised samples from Tiahura, Tubuai, Maiao, Tetiaroa, Pt. Paroa and Tahiti, 1 group comprised samples from Mururoa and Managreva and 3 other groups comprised the isolated samples from Takapoto, Bora-Bora and Nuku-Hiva. Using the Island model, the estimation of the number of effective migrants per generation is between 2.57 and 38.21 . These values, however, probably do not represent the ecological reality. An effective migrant is an individual that migrates to a

Table 4. $F_{\mathrm{s} 1}$ values and jackknife SD estimates (multilocus; Weir \& Cockerham's 1984) for different hierarchical sample groups. Estimates of $\mathrm{N}_{e} \mathrm{~m}$ were derived from the $F_{\mathrm{s} 1}$ values using formulae given in the text. $\mathrm{n}$ : number of individuals

\begin{tabular}{lcccr|}
\hline & $\mathrm{n}$ & $F_{\mathrm{st}}$ & SD (jackknife) & $\mathrm{N}_{\mathrm{e}} \mathrm{m}$ \\
\hline Polynesia (11 populations) & 409 & 0.0886 & 0.0200 & 2.57 \\
Global without Nuku-Hiva & 370 & 0.0536 & 0.0200 & 4.41 \\
Society Archipelago (6 populations) & 222 & 0.0401 & 0.0265 & 5.98 \\
Society Archipelago (without Bora-Bora) & 190 & 0.0213 & 0.0100 & 11.47 \\
Tahiti - Moorea & 110 & 0.0250 & 0.0173 & 9.75 \\
Tetiaroa - Moorea - Maiao & 150 & 0.0065 & 0.0100 & 38.21 \\
Moorea Island (2 populations) & 72 & 0.0164 & 0.0283 & 14.99 \\
\hline
\end{tabular}




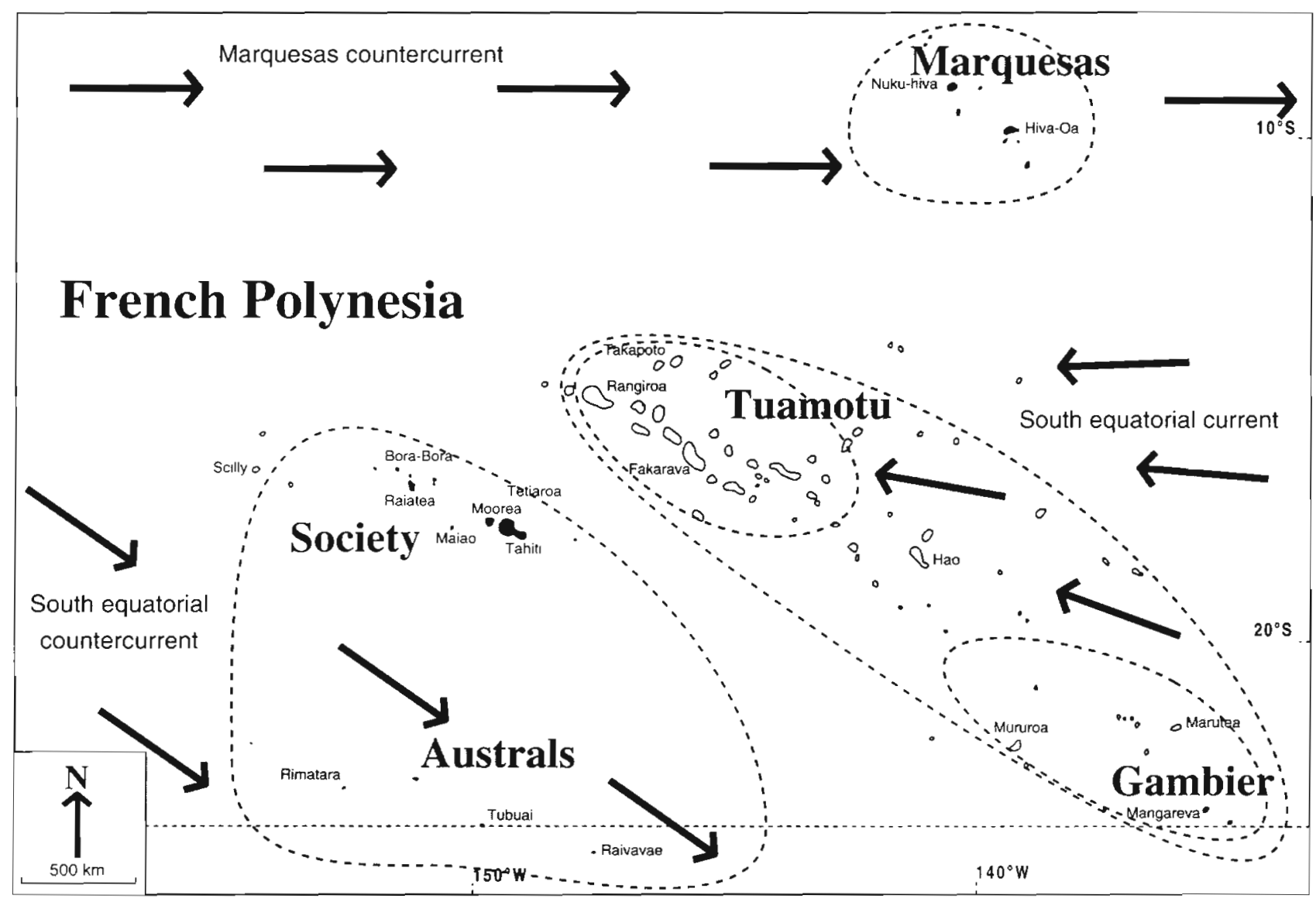

Fig. 3. Acanthurus triostegus. Superimposition of hydrodynamic data and genetic structure of $A$. triostegus in French Polynesia. Dotted lines encircle homogeneous genetic groups

different population and reproduces. This ensures that its genes are incorporated into future generations. Consequently, the real number of migrants is likely to be higher than the estimation suggests. Moreover, we used the Island model commonly used in population genetics, but which does not relate to the ecological data. The stepping-stone model, which required complicated mathematical analysis, would probably be more appropriate and show a higher number of migrants because of restricted gene flow between neighbouring populations (Slatkin 1989). The comparison of these 2 models and the development of mathematical solutions are the subject of a paper in preparation. The estimations of $\mathrm{N}_{\mathrm{e}} \mathrm{m}$ in the present paper give a comparison with other studies.

The genetic consequences of larval dispersal are characterised by the balance between the forces of gene flow (which tend to make gene frequencies uniform among populations) and those of genetic drift and natural selection (which both act to diversify populations) (Wright 1931). Therefore, the observed variation in allelic frequencies in populations of Acanthurus triostegus could be the result of selection, genetic drift or both. The analysis used cannot discern which of selection and genetic drift is the main force causing the observed differentiation. It is assumed, however, that the pattern of biochemical genetic variation observed among populations of $A$. triostegus in French Polynesia is most likely to be the product of genetic drift.

This hypothesis fits the prevailing currents in the area (Rancher \& Rougerie 1992) (Fig. 3). Fig. 3 superimposes currents and genetic data in the Polynesia area. The Marquesas countercurrent is very regular throughout the year. Opposition between this current and the South Equatorial current could explain the strong divergence of the Marquesas population, the border between these 2 currents constituting a barrier for larvae (Vermeij 1987). The genetic differentiation between the Tuamotu-Gambier assemblage and the Society and Australs archipelagoes is weaker, possibly because the border between the South Equatorial current and the South Equatorial countercurrent is more variable during the year and allows larval migration at some times. Since the highest concentrations of acan- 
thurid larvae occur at depths of 13 to $20 \mathrm{~m}$ during the day (Leis 1991), they are likely to be affected by the current system described by Rancher \& Rougerie (1992) in the Polynesian region.

In that context, the significant difference found between Bora-Bora and Moorea, separated by about $250 \mathrm{~km}$, is surprising, as is that between Moorea and Tahiti, both situated in the same archipelago and water mass. The first divergence appears relatively strong because both samples from Moorea (Tiahura and Pt. Paroa) showed a significant difference from Bora-Bora in the allelic frequencies of GDA. However, the divergence between Tahiti and Moorea seems weaker because one sample from Moorea (Tiahura) shows a difference in $S D H$ locus with Tahiti, while the other sample (Pt. Paroa) appears similar to Tahiti. Because of this variability, and even if the $F_{\mathrm{st}}$ between Moorea (pooling Tiahura and Pt. Paroa) and Tahiti shows a significant divergence, no conclusion can be made about the genetic differentiation between Moorea and Tahiti. More samples with greater numbers of individuals will be needed for further studies.

Assuming that differentiation is the result of genetic drift alone, the differentiation between Moorea and Bora-Bora described for Acanthurus triostegus seems to support the hypothesis developed by Johannes (1978) concerning the reproductive strategy of coral reef fish. His observations have shown that many species spawn at times of the year when prevailing winds or currents are at their weakest, and that spawning is concentrated in the vicinity of nearshore gyres which can increase the return of larvae to their natal area. This suggests that larval dispersal is not an adaptation for dispersal of species, but perhaps an evolutionary response to reduce the intense predation pressure of the reefs by transporting larvae offshore (Johannes 1978). Recent studies of larval colonisation have shown that only postflexion larvae are sampled in the reef front (Dufour 1991), suggesting that larvae return to the lagoon when they are competent to settle. Results of the genetic structure of the population of A. triostegus, a species with larval duration of 60 to $70 \mathrm{~d}$, favour the hypothesis of local-recruitment to each island; the existence of gyres around the islands (Lobel \& Robinson 1986, Wolanski \& Hamner 1988) provides the mechanism for this to occur. This hypothesis could cause controversy by changing the current view regarding the evolutionary significance of the oceanic phase of reef fish. However, this situation may also be the result of the unique geomorphology of the Polynesian system, which features very isolated islands without continental plates in-between. Consequently, further studies would be necessary to complete the description of the genetic structure and the gene flow through French Polynesia as well as other locations with different geomorphology.
Acknowledgements. I benefited greatly from the generous support and help provided by many friends and colleagues. I thank J. Algret, M. Calvas, R. Carossi, G. Grosjean, C. Jardin, T. Pambrun and C. Payri for assistance in collecting specimens, and C. Hair for her help with my English. I extend special appreciation to $\mathrm{Mr}$ Ducousso and Mr Bablet of the Service Mixte de Contrôle Biologique (Convention EPHE/SMCB no. 230), P. Cabral of the Etablissement pour la Valorisation des Activités Aquacoles et Maritimes and the Délégation à l'Environnement de Polynésie Française (Convention Bora-Bora no 89-1893). I thank F. Bohomme for the time spent to introduce me to the genetic population world and R. Galzin for making me discover the coral reef ecosystem. J. Bell, D. Colgan, P. Doherty, D. Ferrel, J. Leis and B. Ward read earlier drafts of this manuscript and their comments were greatly appreciated.

\section{LITERATURE CITED}

Allendorf, F. W., Phelps, S. R. (1981). Use of allelic frequencies to describe populations structure. Can. J. Fish. Aquat. Sci. 38: $1507-1514$

Bell, L. J, Moyer, J. T., Nomachi, K. (1982). Morphological and genetic variation in Japanese populations of the anemone fish Amphiprion clarkii. Mar. Biol. 72: 99-108

Dufour, V. (1991). Variation d'abondance des larves de poissons en milieu récifal: effet de la lumière sur la colonisation larvaire. C.r. Acad. Sci., Paris, Série III $187-194$

Emigh, T. H. (1980). A comparison of tests for Hardy-Weinberg equilibrium. Biometrics 36: 627-642

Gorman, G. C., Kim, Y. J. (1977). Genotypic evolution in the face of phenotypic conservativeness: Abudefduf (Pomacentridae) from the Atlantic and Pacific sides of Panama Copeia 1977(4): 694-697

Hourigan, T. F., Reese, E. S. (1987). Mid-ocean isolation and the evolution of Hawaiian reef fishes. Trends Ecol. Evol. (TREE) 2(7): $187-191$

Johannes, R. E. (1978). Reproductive strategies of coastal marine fishes in the tropics. Environ. Biol. Fish. 3 $741-760$

Lacson, J. M. (1992). Minimal genetic variation among samples of six species of coral reef fishes collected at La Parguera, Puerto Rico and Discovery Bay, Jamaica. Mar. Biol. 112: $327-331$

Leis, J M. (1991). Vertical distribution of fish larvae in the Great Barrier Reef lagoon, Australia. Mar. Biol. 109: $157-166$

Lessios, H. A. (1992). Testing electrophoretics data for agreement with Hardy-Weinberg expectations. Mar Biol. 112: $517-523$

Lobel, P. S., Robinson, A. R. (1986). Transport and entrapment of fish larvae by ocean mesoscale eddies and currents in Hawaiian waters. Deep Sea Res. 33: 483-500

Mapstone, B. D., Fowler, A. J. (1988). Recruitment and the structure of assemblages of fish on coral reefs. Trends Ecol. Evol. (TREE) 3(3): 72-77

Nei, M. (1978). Estimation of average heterozygosity and genetic distance from a small number of individuals. Genetics, N.Y. 89: 583-590

Nei, M. (1987). Molecular evolutionary genetics. Columbia University Press, New York

Pasteur, N., Pasteur, G., Bonhomme, F., Catalan, J., BrittonDavidian, J. (1987). Manuel de génétique par électrophorèse des protéines. Lavoisier, Paris

Rancher, J., Rougerie, F. (1992.) Situations océaniques du Pacifique Central Sud. SMSR, Montlhéry 
Randall, J. E. (1961). A contribution to the biology of the convict surgeonfish of the Hawaiian Islands, Acanthurus triostegus sandvicensis. Pacif. Sci. 15(2): 215-272

Randall, J. E. (1985). Fishes. In: Delesalle, B., Galzin, R., Salvat, B. (eds.) 5th int. coral Reef Congr. 1: 462-481

Reynolds, J. B., Weir, B. S., Cockerham, C. C. (1983). Estimation of coancestry coefficient: basis for a short-term genetic distance. Genetics, N.Y 105: $767-779$

Rice, W. R. (1989). Analyzing tables of statistical tests. Evolution 43(1): 223-225

Sale, P. F. (1980). The ecology of fishes on coral reefs. Oceanogr. mar. Biol. A. Rev. 18: 367-421

Shaklee, J. B. (1984). Genetic variation and population structure in the damselfish Stegastes fasicolatus throughout the Hawaiian archipelago. Copeia 1984(3): 629-640

Shaklee, J. B., Allendorf, F. W., Monzot, D. C., Whitt, G. S (1990). Gene nomenclature for protein-coding loci in fish. Trans. Am. Fish. Soc. 119: 2-15

Slatkin, M. (1989). A comparison of three indirect methods for estimating average level of gene flow. Evolution 43(7): $1349-1368$

Somero, G. N., Soulé, M. (1974). Genetic variation in marine fishes as a test of the niche variation hypothesis. Nature 249: 670-671

Sneath, P. H. A., Sokal, R. R. (1973). Numerical taxonomy. W. H. Freeman, San Francisco

This article was presented by M. Pichon, Townsville, Australia
Speith, P. T. (1974). Gene flow and genetic differentiation. Genetics, N.Y. 78: 961-965

Springer, V. G. (1982). Pacific plate biogeography, with special reference to shorefishes. Smithsonian contributions to zoology no. 367. Smithsonian Institution Press, Washington, DC

Vawter, A. T., Rosenblatt, R. H., Gorman, G. C. (1980). Genetic divergence among fishes of the eastern Pacific and the Caribbean: support for the molecular clock. Evolution 34: 705-811

Vermeij, G. J. (1987). The dispersal barrier in the tropical Pacific: implications for molluscan speciation and extinction. Evolution 41: 1046-1058

Weir, B. S., Cockerham, C. C. (1984). Estimating $F$-statistics for the analysis of population structure. Evolution 41(2): 1358-1370

Wolanski, E., Hamner, W. M. (1988). Topographically controlled fronts in the ocean and their biological influence. Science 241: 177-181

Workman, P. L., Niswander, J. D. (1970). Population studies on southwestern India tribes. II. Local genetic differentiation in the Papago. Am. J. Hum. Gen. 22: 24-29

Wright, S. (1931). Evolution in Mendelian populations. Genetics, N.Y. 16: 97-159

Wright, S. (1951). The genetical structure of populations. Ann. Eugen. 15: 322-354

Manuscript first received: September 9,1992

Revised version accepted: June 7, 1993 